\title{
Amphipathic design dictates self- assembly, cytotoxicity and cell uptake of arginine-rich surfactant-like peptides
}

Article

Accepted Version

Mello, L. R., Aguiar, R. B., Yamada, R. Y., Moraes, J. Z., Hamley, I. W., Alves, W. A., Reza, M., Ruokolainen, J. and Silva, E. R. (2020) Amphipathic design dictates self-assembly, cytotoxicity and cell uptake of arginine-rich surfactant-like peptides. Journal of Materials Chemistry B, 8 (12). pp. 24952507. ISSN 0959-9428 doi: https://doi.org/10.1039/c9tb02219h Available at https://centaur.reading.ac.uk/90472/

It is advisable to refer to the publisher's version if you intend to cite from the work. See Guidance on citing.

Published version at: http://dx.doi.org/10.1039/c9tb02219h

To link to this article DOI: http://dx.doi.org/10.1039/c9tb02219h

Publisher: Royal Society of Chemistry

All outputs in CentAUR are protected by Intellectual Property Rights law, including copyright law. Copyright and IPR is retained by the creators or other copyright holders. Terms and conditions for use of this material are defined in the End User Agreement. 


\section{CentAUR}

Central Archive at the University of Reading

Reading's research outputs online 


\title{
Amphipathic Design Dictates Self-Assembly, Cytotoxicity and
}

\section{Cell Uptake of Arginine-rich Surfactant-like Peptides}

\author{
Lucas R. Mello, ${ }^{\text {a }}$ Rodrigo B. Aguiar, ${ }^{\text {a }}$ Renata Y. Yamada, ${ }^{a}$ Jane Z. Moraes, ${ }^{\text {a }}$ Ian W. \\ Hamley, ${ }^{\mathrm{b}}$ Wendel A. Alves, ${ }^{\mathrm{c}}$ Mehedi Reza, ${ }^{\mathrm{d}}$ Janne Ruokolainen ${ }^{\mathrm{d}}$ and Emerson R. Silva ${ }^{\mathrm{a}}$ \\ aDepartamento de Biofísica, Universidade Federal de São Paulo, 04044-020, São Paulo, Brazil; bepartment of \\ Chemistry, University of Reading, Whiteknights, Reading, RG6 6AD, UK; ' Centro de Ciências Naturais e Humanas, \\ Universidade Federal do ABC, 09210-580, Santo André, Brazil; ${ }^{\mathrm{d} N a n o m i c r o s c o p y ~ C e n t e r, ~ A a l t o ~ U n i v e r s i t y, ~}$ \\ Puumiehenkuja 2, FIN-02150 Espoo, Finland
}

\begin{abstract}
Amphiphilicity is the most critical parameter in the self-assembly of surfactantlike peptides, regulating the way by which hydrophobic attraction holds peptides together. Its effects go beyond supramolecular assembly and may also trigger different cell responses of bioactive peptide-based nanostructures. Herein, we investigate the selfassembly and cellular effects of nanostructures based on isomeric surfactant-like peptides composed by arginine (R) and phenylalanine (F). Two amphipathic designs were studied: a diblock construct $\mathrm{F}_{4} \mathrm{R}_{4}$ and its bolaamphiphile analog $\mathrm{R}_{2} \mathrm{~F}_{4} \mathrm{R}_{2}$. A strong layoutdependent polymorphism emerges with appearance of globules and vesicle-like assemblies, or flat nanotapes and cylindrical micelles. The diblock construct possesses good cell penetrating capabilities and effectiveness to kill SK-MEL-28 melanoma tumor cells, in contrast to reduced intracellular uptake and low cytotoxicity exhibited by the bolaamphiphilic form. Our findings demonstrate that amphipathic design is a relevant variable for self-assembling SLPs to modulate different cellular responses and may assist in optimizing the production of nanostructures based on arginine-enriched sequences in cell penetrating and antimicrobial peptides.
\end{abstract}

*Corresponding author: er.silva@unifesp.br 


\section{INTRODUCTION}

Nanostructures made up from surfactant-like peptides (SLPs) are outstanding materials in cutting-edge fields of biomolecular engineering, nanobiology and nanomedicine. ${ }^{1-4}$ The impressive properties displayed by these supramolecular systems are closely related to the designability of peptides, which are highly programmable molecules whose physiochemistry can be controlled through intelligent choice and appropriate disposition of amino acids. ${ }^{5}$

Amphiphilicity is the most critical parameter playing a role for the final organization of self-assembling SLPs. ${ }^{6}$ Despite many interactions such as H-bonding and Coulomb electrostatics are implied in self-assembly, amphiphilicity regulates the way by which hydrophobic attraction holds peptides together, and thus it affects intensity of other intermolecular forces. In addition to polarity of single amino acids, amphiphilicity is also influenced by the relative position of hydrophilic and hydrophobic residues in the peptide sequence. The most usual molecular layouts found in SLPs comprises a hydrophobic amino acid block covalently attached to a "headgroup" composed of ionic residues, mimetizing the overall shape of detergents. ${ }^{4,7}$ A second group, differing in terms of linkage pattern, are the so-called bolaamphiphiles, which are amphipathic molecules where a central hydrophobic segment is linked to charged amino acids at both termini.

Recently, several few works have explored sequence pattern variation of isomeric peptides to control the final shape of nanostructures. ${ }^{8-12}$ A remarkable example of this endeavor is the work by Cui et al. demonstrating that palmitoylated isomers alternating valine/glutamic acid residues - i.e., $\mathrm{C}_{16}$-VEVE and $\mathrm{C}_{16}$-EVEV - produce tape-like structures, whereas analogs carrying block segments $\left(\mathrm{C}_{16}\right.$-VVEE and $\mathrm{C}_{16}$-EEVV) selfassemble into cylindrical fibers. ${ }^{8}$ More recently, designed isomers have been exploited in the regulation of in vitro release of hydrogen sulfide into cardiomyocytes ${ }^{9}$ whereas 
designed glycopeptides have been shown to possess switchable antibiofilm properties. ${ }^{10}$ However, as a rule, these studies have not provided direct comparison between isomeric sequences with distinct amphipathic designs in terms of the supramolecular polymorphism and cell response of peptide-based nanostructures.

Herein, octameric sequences containing arginine and phenylalanine have been synthesized either with a diblock layout - i.e., FFFFRRRR-NH $\mathrm{N}_{2}$ - or with a bolaamphiphile design of composition RRFFFFRR-NH$H_{2}$. These highly-simplified sequences incorporate only two amino acid species in their composition and previous investigations on oligopeptides containing the alternating pair $[\mathrm{RF}]$ demonstrated that these models show all main features of complex amyloidogenic peptides. ${ }^{13-15}$ These peptides are highly cationic, arginine-enriched sequences, thus keeping correlation with prominent classes of bioactive peptides, namely, antimicrobial and cell-penetrating peptides. Also, both constructs have the same amino acid composition, and exhibit the same overall charge and hydrophobicity, which enables the investigation of the effects of amphipathic layout on final properties without influence of other factors associated to amino acid variation. We investigate the supramolecular organization of these SLPs through a range of structural techniques and study their effects on SK-MEL-28 human skin melanoma cells by fluorescence, metabolic and flow cytometry assays. A major motivation of our study is that amphipathic design has not yet been addressed in the context of isomeric sequences, and arginine-based SLPs such as those described here are a relevant topic due to prominent role of this amino acid in bioactive compounds including cell penetrating ${ }^{16,17}$ and antimicrobial peptides. ${ }^{18,19}$ Our results show profound effects of amphipathic design on the morphology of self-assembled aggregates and a rich polymorphism emerges with the formation of globular micelles and vesicles, or flat nanotapes and cylindrical micelles, depending on amphiphilic layout and peptide 
concentration. While the bolaamphiphile variant has been found to show poorer cellpenetrating capabilities, the diblock $\mathrm{F}_{4} \mathrm{R}_{4}$ presented good cell uptake rates, being able to reach nucleoli structures and efficiently promote cell death. These findings demonstrate that amphipathic layout is a relevant variable for self-assembling SLPs to modulate different cellular responses and may assist in optimizing the production of nanostructures based on arginine-enriched sequences such is the case for most cell penetrating and antimicrobial peptides

\section{METHODS}

Peptide materials and sample preparation: peptide octamers were synthesized by CS Bio (Merlo Park, California) and delivered in the form of TFA salt. The following sequences were synthesized: FFFFRRRR-NH $\mathrm{NH}_{2}$ (henceforth referred to as "diblock" peptide and shortened to $\mathrm{F}_{4} \mathrm{R}_{4}$ ) and RRFFFFRR-NH ("bolaamphiphile" peptide, $\mathrm{R}_{2} \mathrm{~F}_{4} \mathrm{R}_{2}$ ). Standard solid-phase approaches, with Fmoc protected amino acids, were used to produce the sequences. Purities were assessed through HPLC and purity was determined to be $98.8 \%$ and $97.6 \%$, respectively, for diblock and bolaamphiphile peptides (see SI file, Fig. S1). Molecular masses were determined through electrospray-mass spectrometry assays at $\mathrm{M}_{\mathrm{w}}=1231.02$ and $1231.18 \mathrm{Da}$ (expected value: 1230.47$)$. Further liquid chromatography and mass-spectroscopy tests performed at our lab confirmed the levels of purities and molecular masses informed by the manufacturer. Samples were prepared by weighting lyophilized peptides into test tubes and dissolving them into ultrapure water (or $\mathrm{D}_{2} \mathrm{O}$ ) to the desired concentration. Peptides were considered completely dissolved when solutions became transparent, which was achieved immediately after dissolution. Transparent solutions from samples containing peptides at $100 \mathrm{mg} / \mathrm{ml}$ could be obtained by sonicating the vials for a few minutes at room 
temperature. Solutions were kept in the fridge for a couple of days prior to SAXS, FTIR and cryo-EM experiments. To avoid pyrene aggregation in fluorescence assays, solutions were left to equilibrate overnight in the dark at room temperature and then examined.

Fourier-transform Infrared Spectroscopy (FTIR). solutions prepared in $\mathrm{D}_{2} \mathrm{O}$ were investigated using a Nicolet Nexus spectrophotometer. Samples containing $1 \mathrm{wt} \%$ peptide were carefully placed between $\mathrm{CaF}_{2}$ windows separated by $12 \mu \mathrm{m}$ mica spacers. The spectral range investigated corresponded to the amide region and spectra were collected at a resolution of $4 \mathrm{~cm}^{-1}$. Data were background-subtracted and peak deconvolution was carried out using Fityk program. ${ }^{20}$

Small-angle X-ray Scattering: Small-angle X-ray Scattering (SAXS) measurements were carried out either on SAXS-1 at LNLS (Campinas, Brazil) or on beamline SWING at SOLEIL (Gif-sur-Yvette, France). On SAXS-1 beamline, $300 \mu$ of solution were loaded with a syringe into a $1 \mathrm{~mm}$ cell between mica windows. Ten frames of $30 \mathrm{~s}$ each were collected, compared and, if no radiation damage was noticed, they were averaged, and background subtracted. The X-ray energy was kept at $8 \mathrm{keV}$ and sample-to-detector distance was measured at $893 \mathrm{~mm}$ from calibration using a silver behenate standard. Data collection was carried out with a Pilatus $1 \mathrm{M}$ detector and the accessible $q$-range was 0.12 $\mathrm{nm}^{-1} \leq q \leq 4.5 \mathrm{~nm}^{-1}$. On SWING at SOLEIL, the X-ray wavelength was set at $\lambda=1.03 \AA$ and the sample-to-detector distance was set at 1,526 mm. Data collection was performed using a 2D Aviex 170170 detector, leading a $q$-range $0.04 \mathrm{~nm}^{-1} \leq q \leq 4.5 \mathrm{~nm}^{-1}$. The bioSAXS setup, which allowed automatic sample change, was used to inject about $50 \mu \mathrm{L}$ of peptide solution into a $1 \mathrm{~mm}$ quartz-capillary. To avoid radiation damage, 50 frames (500 ms per frame) were grabbed during flow through the capillary. Automated washing steps were performed between every measurement and background assessments were 
made prior to and after sample registering. Model fitting was carried by using the SASFit $\operatorname{program}^{21}$

Cryo-transmission electron microscopy (cryo-TEM) assays were performed as detailed elsewhere. ${ }^{15}$ In brief, a JEOL JEM-3200FSC microscope operating at $300 \mathrm{kV}$ and a Gatan Ultrascan 4000 CCD camera were used to examined the samples. Aliquots with $3 \mu \mathrm{l}$ of peptide solutions were cast on copper grids and blotted once for $1 \mathrm{~s}$. Vitrification was carried out in a FEI Vitrobot device using a 1:1 ethane:propane mixture at $-180^{\circ} \mathrm{C}$. Grids with vitrified samples were maintained in a liquid nitrogen atmosphere and then cryo-transferred into the microscope.

Cell Culture: SK-MEL-28 melanoma cells (ATCC, USA) were cultured in RPMI-1640 medium (Sigma, USA) supplemented with 10\% fetal bovine serum (FBS; Gibco BRL, Brazil). Cells were maintained at $37{ }^{\circ} \mathrm{C}$ in $5 \% \mathrm{CO}_{2}$ and were checked for Mycoplasma contamination.

MTT assay: Cell metabolic viability was determined by the 3-(4,5-Dimethylthiazol-2yl)-2,5-diphenyltetrazolium bromide (MTT) assay. SK-MEL-28 cells $\left(1 \times 10^{4}\right.$ cells/100 $\mu \mathrm{L} /$ well) were plated into 96 -well plates and incubated for $4 \mathrm{~h}$ with diblock $\mathrm{F}_{4} \mathrm{R}_{4}$ or bolaamphiphile $\mathrm{R}_{2} \mathrm{~F}_{4} \mathrm{R}_{2}$. The peptides were diluted in culture medium to concentrations ranging from 0.05 to $6.60 \mathrm{mg} / \mathrm{mL}$. Vehicle as used as a control. Subsequently, cells were incubated for $3 \mathrm{~h}$ with $0.5 \mathrm{mg} / \mathrm{ml}$ MTT (Sigma, USA), and the formed formazan crystals were dissolved in DMSO. The absorbance was read at $595 \mathrm{~nm}$. Data were plotted and analyzed by nonlinear regression using GraphPad Prism software (GraphPad software, USA) ( $\mathrm{r}^{2}$ was close to 1$)$. The $50 \%$ effective concentration $\left(\mathrm{EC}_{50}\right)$ values were calculated using the Hill equation. The experiment was performed in quadruplicate and repeated three times. 
Assessment of cell death and viability: $1 \times 10^{6}$ SK-MEL-28 cells were seeded into 24well plates and incubated for 4 and $24 \mathrm{~h}$ with diblock $\mathrm{F}_{4} \mathrm{R}_{4}$ or bolaamphiphile $\mathrm{R}_{2} \mathrm{~F}_{4} \mathrm{R}_{2}$ peptides at the respective $\mathrm{EC}_{50}$. Cell death was measured by propidium iodide (PI) uptake as described. ${ }^{22}$ For that, cells were harvested and incubated with $10 \mu \mathrm{g} / \mathrm{mL}$ of PI (Thermo, USA) for $15 \mathrm{~min}$. A total of 10,000 events/sample were analyzed on a BD Accuri ${ }^{\mathrm{TM}}$ C6 cytometer (BD Biosciences, USA) and the percentage of PI-positive cells was detected. The number of viable cells was assessed by flow cytometry ${ }^{22,23}$ and the trypan blue exclusion assay. ${ }^{24}$ Images of the cells were acquired with phase contrast microscopy using a 40× objective (Leica, USA). All experiments were performed in duplicate and repeated at least two times.

Fluorescence assay: Fluorescence assays were performed with cells incubated with biotin-labeled peptides. The biotinylation was carried out using the EZ-Link Sulfo-NHSBiotin kit. The peptides were completely dispersed into ultrapure water and then were mixed with sulfo-NHS-LC-Biotin reagent, according to the manufacture instructions. To evaluate the cellular uptake and intracellular distribution of $\mathrm{F}_{4} \mathrm{R}_{4}$ and $\mathrm{R}_{2} \mathrm{~F}_{4} \mathrm{R}_{2}, 1 \times 10^{5} \mathrm{SK}$ MEL-28 cells were plated on coverslips in 24-well plates and incubated for 30 min with biotinylated peptide mixture at the EC50. Vehicle was used as a control. After incubation, cells were fixed with $1 \%(\mathrm{~m} / \mathrm{v})$ paraformaldehyde and then blocked with $1 \%(\mathrm{~m} / \mathrm{v})$ BSA in phosphate-buffered saline (PBS). Biotin-labeled peptides were detected with Alexa Fluor® 488-conjugated streptavidin (Thermo, USA) diluted 1:200 in blocking buffer. All steps were followed by PBS washes. Nuclei were stained with DAPI. Images were captured on a Leica TCS SP8 microscope (Leica, Germany) with a 40x objective and then analyzed with ImageJ software. The experiment was performed in duplicate and repeated three times. 
All steps were followed by PBS washes. Nuclei were stained with DAPI. Images were captured on a Leica TCS SP8 microscope (Leica, Germany) with a 40x objective and then analyzed with ImageJ software. The experiment was performed in duplicate and repeated three times.

Statistical analysis: Differences between groups were statistically evaluated by Student's $t$-test or by one-way ANOVA followed by Bonferroni's post-test, as indicated. $\mathrm{P}<0.05$ was considered significant.

\section{RESULTS AND DISCUSSIONS}

\section{Spectroscopy studies:}

We aimed to investigate how primary structure affects the supramolecular organization of self-assemblies formed by diblock and bola-form peptides. Our first step in this endeavor was using the pyrene method ${ }^{25}$ to determine critical aggregation concentrations (CACs) required for spontaneous assembly of peptide monomers into ordered nanostructures. Samples containing a fixed amount of pyrene were co-solubilized with peptides at concentrations ranging from $\sim 10^{-4}$ to $\sim 3 \mathrm{mg} / \mathrm{ml}$ and fluorescence assays were carried out by exciting the mixtures with ultraviolet light at $\lambda_{\text {exc }}=338 \mathrm{~nm}$ and monitoring emission intensities at $\lambda_{\mathrm{em}}=373 \mathrm{~nm}$ and $\lambda_{\mathrm{em}}=384 \mathrm{~nm}$. These emission wavelengths correspond to $I_{1}$ and $I_{3}$ vibronic bands, ${ }^{26}$ respectively, and the $I_{1} / I_{3}$ ratio is decreases when pyrene molecules are surrounded by nonpolar environments; ${ }^{25}$ thus, by investigating the behavior of $\mathrm{I}_{1} / \mathrm{I}_{3}$ as a function of peptide concentration, it has been possible to get insights into the formation of hydrophobic aggregates in the solutions. In Figure $1 \mathrm{~A}$ and $\mathrm{B}, \mathrm{I}_{1} / \mathrm{I}_{3}$ vs. $\log [$ peptide] plots exhibit sigmoidal profiles with two emission regimes separated by a smooth transition. This behavior, where $I_{1} / I_{3}$ ratio decays upon increase of peptide concentration, is consistent with migration of pyrene from the aqueous 
phase to peptide hydrophobic cores ${ }^{25,26}$ and CAC values could be derived from inversion points in the sigmoids. The data were properly fitted using a sigmoidal function ${ }^{15,25}$ (red lines in $1 \mathrm{~A}$ and $\mathrm{B}$ ) and inflection points were accurately determined from minima found in first derivative plots of the curves (dotted lines). In addition, measurements of the full width at half maximum of the minima allowed us to estimate the concentration range corresponding to uncertainties in these critical values. In the case of the $F_{4} R_{4}$ diblock peptide, the transition range is in the interval $0.12-0.40 \mathrm{mg} / \mathrm{ml}$, with crossover point centered at $\mathrm{CAC}=0.21 \mathrm{mg} / \mathrm{ml}$. In the case of the bolaamphiphilic form, $\mathrm{R}_{2} \mathrm{~F}_{4} \mathrm{~F}_{2}$, the transition occurs over a larger range of concentrations, between 0.002 and $0.027 \mathrm{mg} / \mathrm{ml}$, with critical value at $\mathrm{CAC}=0.008 \mathrm{mg} / \mathrm{ml}$. The difference between CAC values above is a first evidence for the influence of amphipathic layout in physicochemical properties of SLPs. In fact, both molecules have the same overall amphipathicity, however surface charge distribution along the sequence likely plays a role for self-assembly. Indeed, the bolaamphiphile $\mathrm{R}_{2} \mathrm{~F}_{4} \mathrm{R}_{2}$ possess higher propensity to form discrete nanostructures in solution in comparison to the diblock peptide and a possible explanation for this could be related to the higher electron density of the tetra-arginine segment in the $F_{4} R_{4}$ chain making inter-strand association energetically costly.

The secondary structure of peptide aggregates was also investigated through circular dichroism (CD) and Fourier-transform infrared (FTIR) spectroscopy. The extensive presence of phenylalanine residues these amphipathic peptides leads to CD spectra featured by strong maxima at $\sim 220 \mathrm{~nm}$, resulting from electronic transitions of aromatic side chains (see SI file for details, Fig. S2). In addition to intense phenyl transitions, CD data are characterized by deep negative rotations at $200 \mathrm{~nm}$ which could be indicative of disordered content in the aggregates. ${ }^{27}$ Interestingly, the signature of $F_{4} R_{4}$ aggregates shows a broad minimum near to $230 \mathrm{~nm}$, which is not usual for canonical 
secondary structures found in polypeptides, suggesting that it arises from other electronic effects such as $\pi-\pi$ stacking or $\beta$-sheet distortions. ${ }^{12}$ To get further information on secondary structure, we examined FTIR signatures of concentrated samples. The concentrations in these assays are much larger than the CAC values and the presence of peptide nanostructure is ensured. In Figures $1 \mathrm{C}$ and D, FTIR data from $50 \mathrm{mg} / \mathrm{ml}$ solutions prepared using $\mathrm{D}_{2} \mathrm{O}$ as a solvent indicate very characteristic resonances across the amide I band and part of the amide II region. The infrared spectra clearly exhibit overlapped peaks and to properly discriminate resonances associated to different chemical groups, we carried out peak deconvolution by using Pearson VII functions. One observes that spectra are dominated by a strong vibration at $1673 \mathrm{~cm}^{-1}$, which is assigned to the presence of TFA counterions in the samples. ${ }^{15}$ Remarkable resonances also appear at $1585 \mathrm{~cm}^{-1}$ and $1607 \mathrm{~cm}^{-1}$ for both peptides. The peak at $1585 \mathrm{~cm}^{-1}$ could be attributed to anti-symmetric stretching of guanidinium groups in arginine side-chains, whereas vibration at $1607 \mathrm{~cm}^{-1}$ could be tentatively assigned to relaxation of aromatic rings in the tetra-phenylalanine segments. ${ }^{28}$ In addition to contribution from aromatic groups, arginine side-chains also have been reported to exhibit a shallow infrared band near to $1607 \mathrm{~cm}^{-1}$ due to symmetric stretching of $\mathrm{CN}_{3} \mathrm{H}_{5}{ }^{+}$and its extensive presence in the amino acid sequences likely strengthens this peak in the spectra. ${ }^{28}$ The presence of unordered conformations in aggregates is indicated by strong bands at 1643 and $1645 \mathrm{~cm}^{-1}$, respectively, for $R_{2} F_{4} R_{2}$ and $F_{4} R_{4}$. Deconvolution also reveals that bands in spectra from $\mathrm{F}_{4} \mathrm{R}_{4}$ solutions are broader than those found in samples containing the bolaamphiphilic analog, thus indicating that chemical groups in supramolecular arrangements built up by the diblock peptide present higher conformational freedom. ${ }^{29}$ Interestingly, a band at $1627 \mathrm{~cm}^{-1}$ was found in samples containing $\mathrm{F}_{4} \mathrm{R}_{4}$, indicating the presence of some $\beta$-sheet content in aggregates formed from self-assembling diblock peptide. In the case of the 
bolaamphiphilic sequence, however, this band is suppressed and no infrared evidence for $\beta$-sheets has been found.

Altogether, CD and FTIR data indicate that secondary structure of aggregates based on these arginine/phenylalanine peptides is dominated by disordered conformations, in substantial contrast to $\beta$-sheet-enriched assemblies usually formed by sequences alternating hydrophobic/hydrophilic residues. ${ }^{14,15}$ The bolamphiphilic construct does not form $\beta$-sheets, and $\mathrm{F}_{4} \mathrm{R}_{4}$ only adopts $\beta$-sheet conformation at high concentrations. The main reason for this is related to the tetraphenylalanine segment in the isomers and its H-bonding capabilities. The formation of $\beta$-sheets is mediated by intermolecular $\mathrm{H}$-bonds between adjacent strands, and appearance of this secondary structure in self-assembling peptides is normally correlated to intercalation of residues containing strong H-bond donors/acceptors. ${ }^{6,30}$ Phenylalanine can form only weak Hbonds through $\mathrm{CH}-\pi$ interactions, ${ }^{31}$ and its stacking, without intercalating any stronger H-bonding amino acid, likely depress the formation of $\beta$-sheets. In the case of $\mathrm{F}_{4} \mathrm{R}_{4}$, the formation of $\beta$-sheet content is presumably driven by the tetrameric arginine segment. In contrast, for the $\mathrm{R}_{2} \mathrm{~F}_{4} \mathrm{R}_{2}$ analog, it seems that only two arginines next to each terminal are not able to remain sufficiently aligned to develop strong H-bonding and generate $\beta$-sheets. As discussed below, these secondary structure features are closely related to morphology assumed by supramolecular assemblies, and formation of $\beta$-sheets by diblock amphiphile is associated to appearance of worm-like micelles whereas their absence in bolaamphiphile aggregates could be likely related to interdigitation of peptide across flat nanotapes. 

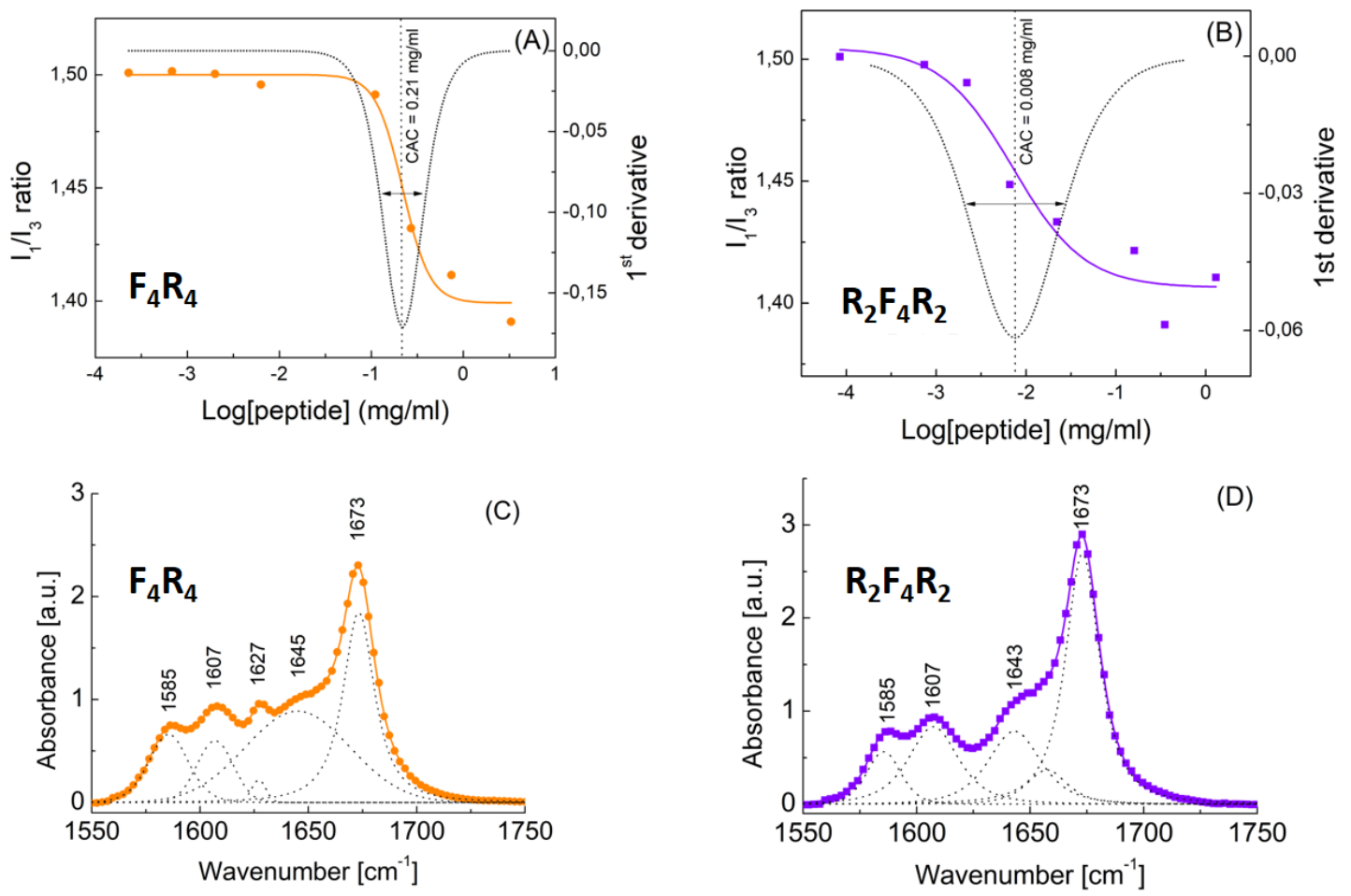

Figure 1: (A) and (B) Behavior of pyrene $I_{1} / I_{3}$ ratio as a function of the logarithm of peptide concentration. Solid lines are least-square fits according to sigmoid functions whereas dotted lines correspond to their corresponding first derivatives. (C) and (D) Infrared spectra from solutions containing peptides at $50 \mathrm{mg} / \mathrm{ml}$ in $\mathrm{D}_{2} \mathrm{O}$. Solid lines are the sum of peak deconvoluted functions (dotted lines).

\section{Amphipathic design dictates polymorphism in SLPs:}

Cryogenic transmission electron microscopy (cryo-TEM) imaging was carried out on vitrified samples to provide insights into the morphology of peptide aggregates. In Figure $2 \mathrm{~A}$ and $\mathrm{B}$, panels with representative micrographs from samples prepared at 10 $\mathrm{mg} / \mathrm{ml}$ reveal extensive presence of discrete nanoassemblies with shapes and sizes dependent on primary structure of the sequences used in the preparations. The selfassembly is complex and mixed populations of nanoparticles exhibiting different morphologies appear in the samples. In the case of $\mathrm{F}_{4} \mathrm{R}_{4}$, samples have been found to be extensively populated by globular nanostructures, comprising micelles and vesicles, with 
dimensions varying in the range of a few tens of nanometers (Figure 2A). Indeed, the smallest aggregates observed in these solutions are micelles with diameters near to 12 $\mathrm{nm}$, and the presence of elongated structures is compatible with lateral association between micelles. Interestingly, spheroids with diameters in the range $30-40 \mathrm{~nm}$ were also observed in samples prepared with the diblock peptide and the systematic presence of high-contrast cores strongly suggests that these assemblies are vesicles. This behavior is consistent with the surfactant-like design of the diblock peptide used in this study, where the tetra-arginine segment mimics a polar head whereas the tetra-phenylalanine block resembles an alkyl chain. Particularly, single-headed surfactants can self-assemble into flexible bilayers and form vesicles. ${ }^{32}$
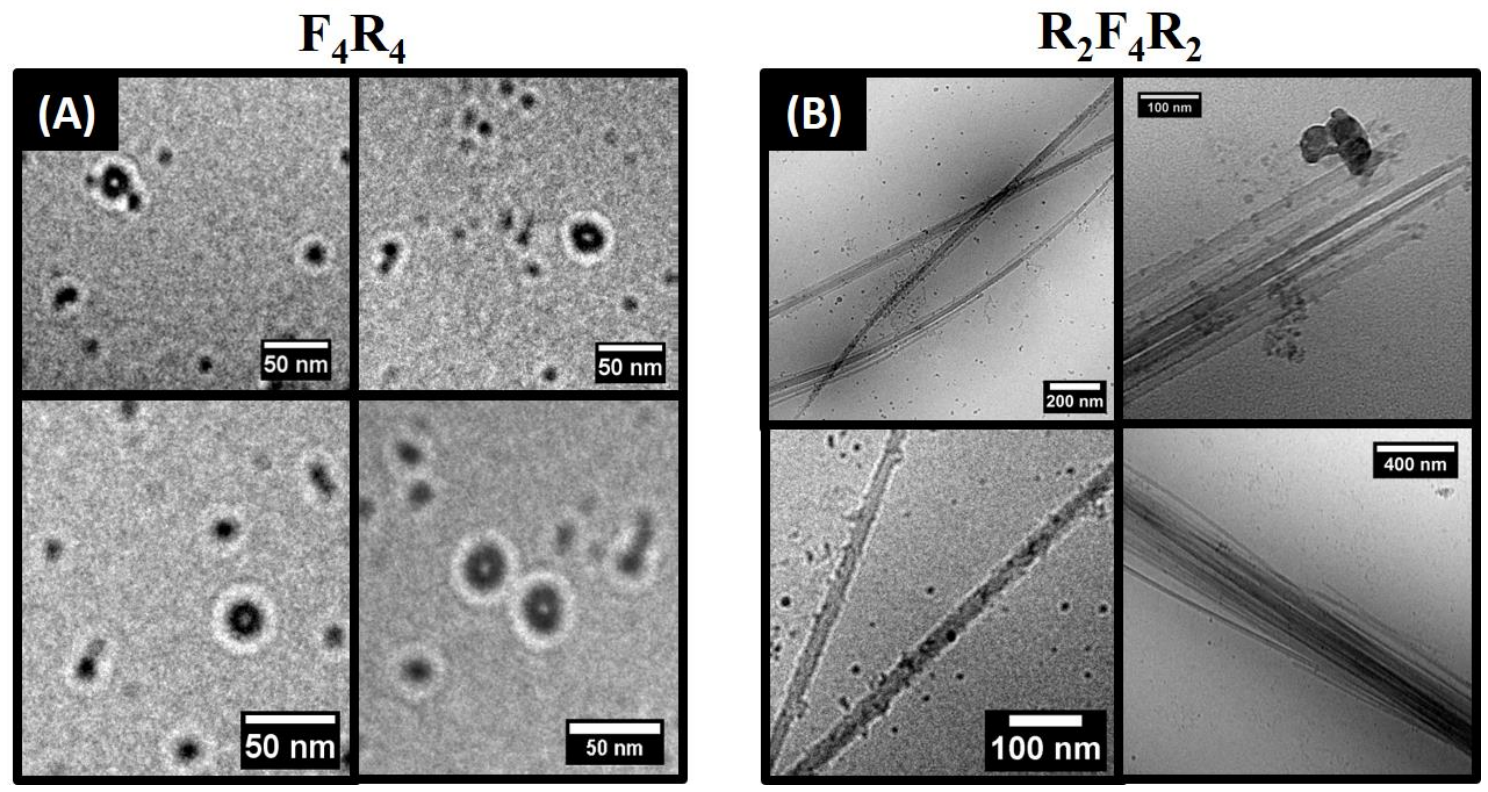

Figure 2: Cryo-EM micrographs from vitrified solutions containing peptides at 10 $\mathrm{mg} / \mathrm{ml}$. (A) $\mathrm{F}_{4} \mathrm{R}_{4}$ self-assembles into micelles and vesicles (indicated by bright cores) whereas (B) $\mathrm{R}_{2} \mathrm{~F}_{4} \mathrm{R}_{2}$ is organized into micelles and tape-like structures.

Cryo-EM images from solutions containing the bolaamphiphile $\mathrm{R}_{2} \mathrm{~F}_{4} \mathrm{R}_{2}$ also indicated the presence of nanoscopic micelles (Figure 2B). In general, dimensions of these aggregates are smaller in comparison to those observed for $\mathrm{F}_{4} \mathrm{R}_{4}$ peptides and their 
typical diameters are near to $6 \mathrm{~nm}$. In coexistence with small aggregates, the formation of very long nanotapes with thicknesses of about $11 \mathrm{~nm}$ was observed. In some aggregates, nanotapes were aligned parallel to each other and formed larger structures with thicknesses spanning up to $~ 110 \mathrm{~nm}$, equivalent to ten subunits placed side-by-side. These long structures are highly anisotropic and exhibit high aspect ratios with lengths easily reaching the micrometer range. Also, the nanotapes display high persistence lengths as attested by absence of twisting, folding or highly curved regions across the long axis. These findings agree with the double-headed design of the $\mathrm{R}_{2} \mathrm{~F}_{4} \mathrm{R}_{2}$ peptide and corroborate the reported propensity of arginine-capped bolaamphiphile peptides to form stable monolayers. ${ }^{7,33-35}$ Herein, $\mathrm{R}_{2} \mathrm{~F}_{4} \mathrm{R}_{2}$ sequences presumably self-assemble through lateral association between peptide chains where tetra-phenylalanine segments construct the core and arginine heads remain exposed at both interfaces of the nanotapes.

SAXS measurements were performed to complement cryo-EM and assist structural elucidation of these aggregates in solution. Synchrotron SAXS is one of the most versatile tools to investigate shapes and sizes of macromolecules in solution since it provides in situ information. In addition, the technique gives average information from a large number of particles in the sample, in contrast to microscopy methods which provide visualization from a limited number of representative assemblies. Experiments carried out on beamline SWING at SOLEIL afforded data over a large $q$-range, from 0.007 to 7 $\mathrm{nm}^{-1}$, covering lengths from $\sim 900 \mathrm{~nm}$ down to the sub-nanometer scale. This wide range of $q$-vectors allowed us to simultaneously derive information from both the macrostructure and the inner structure of aggregates and the resulting fitting parameters are shown in Table S1 (SI file). 

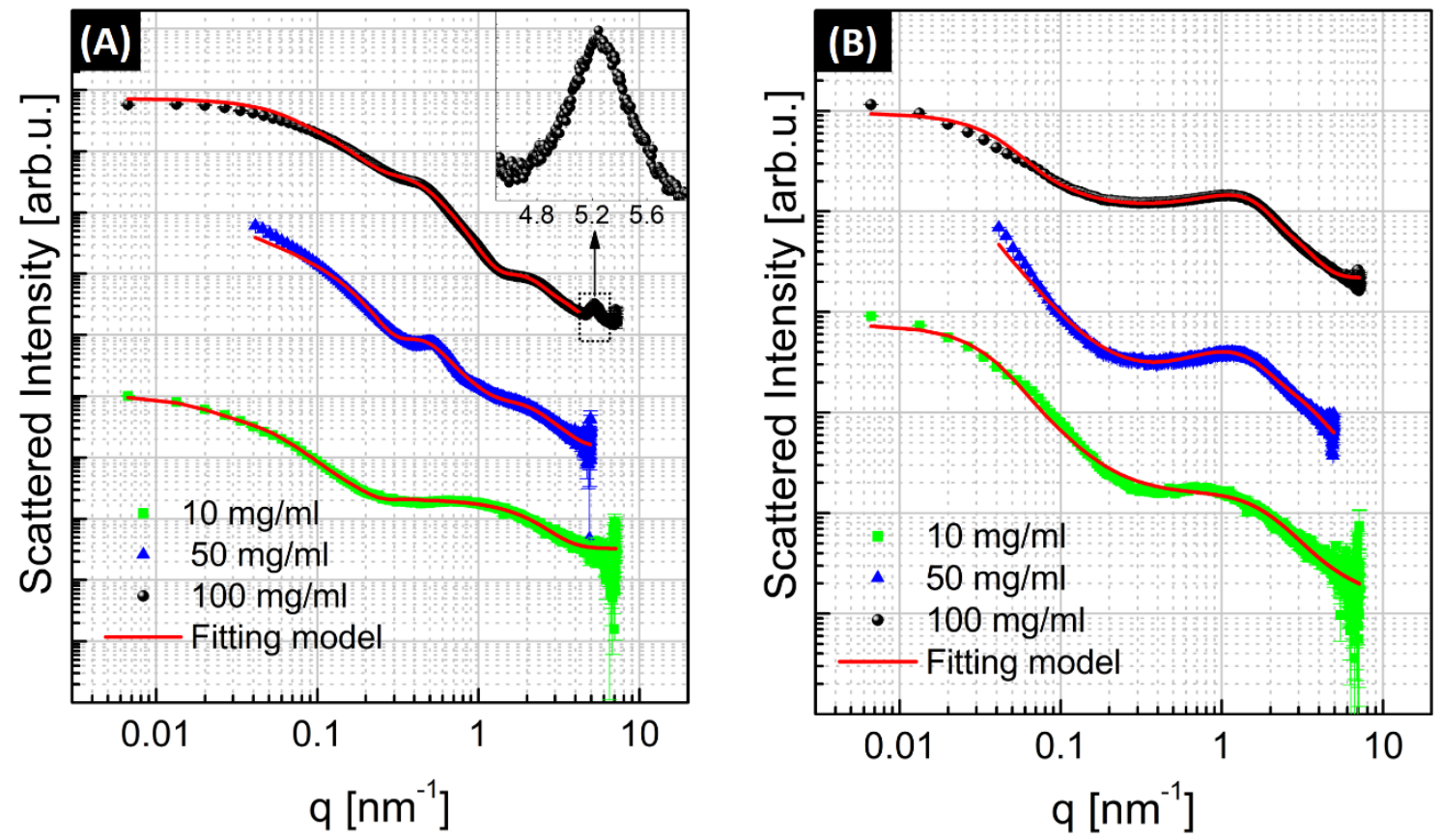

Figure 3: SAXS data from solutions containing peptides at concentrations indicated. Inset in (B): $\beta$-sheet peak centered at $q=5.26 \mathrm{~nm}^{-1}$ observed at the highest concentration of the diblock peptide. Differences in $q$-range are due to data collection on different beamlines (see text for details).

In Figs $3 \mathrm{~A}$ and $\mathrm{B}$, we show scattering profiles from solutions with concentrations varying between 10 and $100 \mathrm{mg} / \mathrm{ml}$. The outlines of the curves evidence that both primary structure and peptide concentration have strong influence on the shapes present in solution and reveal a rich supramolecular polymorphism of $F_{4} R_{4}$ and $R_{2} F_{4} R_{2}$ sequences. At the lowest $q$ values, the curves are characterized by a flat plateau indicating that both inter-particle repulsion and coalescence of nanoscopic self-assemblies are absent even at the highest concentration investigated. ${ }^{36}$ Similarly to cryo-EM, SAXS data show that the self-assembly is very complex, with mixed morphologies appearing in the medium, and full-range model fitting is particularly challenging since multiple structural levels are found across length scales available in the data. In samples prepared with $F_{4} R_{4}$ at 10 
$\mathrm{mg} / \mathrm{ml}$ (green squares in Fig. 3A), least-square fits could be performed by combining a spherical shell form factor ${ }^{37}$ plus a mass fractal form factor. ${ }^{15,37}$ Scattering in the low- $q$ region is dominated by larger particles and the presence of spherical shells is consistent with the appearance of peptide vesicles observed in cryo-EM images (see Fig. 3A). To account for polydispersity of particles in the solutions, Gaussian polydispersity in the radius of spherical shells was included. The fits indicate highly-polydisperse vesicles with average radius $19.2 \pm 16.0 \mathrm{~nm}$ and outer shells around $6.5 \mathrm{~nm}$, consistent with dimensions of vesicles found in cryo-EM images. A schematic drawing of the vesicles, with the corresponding parameters extracted from SAXS measurements, is shown in Fig. 4A. On the other hand, in the high- $q$ range, scattering arises from smaller particles and a model fit according to mass fractals disclose assemblies with gyration radii around $0.8 \mathrm{~nm}$, consistent with oligomer species containing a few peptide monomers. ${ }^{14}$

Interestingly, higher $\mathrm{F}_{4} \mathrm{R}_{4}$ concentrations lead to profound changes in SAXS profiles and a remarkable oscillation at intermediate $q$-range appears at $\mathrm{q} \sim 0.5 \mathrm{~nm}^{-1}$ in samples containing $50 \mathrm{mg} / \mathrm{ml}$ and $100 \mathrm{mg} / \mathrm{ml}$ peptide. Spherical shell form factors were not suitable for describing the small-angle region of these curves and a slope decay scaling with $\mathrm{q}^{\sim-1}$ across the intermediate range suggested the existence of elongated structures in the solutions. Data from these concentrated samples could be properly fitted according a combination of long cylinder shells and mass fractal form factors (upper curves in Fig. 3A). Polydispersity was described by Gaussian functions associated to the radius of cylindrical objects. In the case of the formulation prepared at $50 \mathrm{mg} / \mathrm{ml}$, fitting parameters for the cylindrical shell component were $3.2 \pm 1.9 \mathrm{~nm}$ and $4.2 \mathrm{~nm}$, respectively, for the radius of the inner core and shell thickness. A sketch of the cylindrical shell model is shown in Fig. 4B. These findings suggest that these larger structures are polydisperse cylindrical micelles arising from association between smaller 
spherical micelles such as those observed in cryo-EM at lower concentrations. This effect is consistent with the lyotropic behavior exhibited by surfactant block copolymers where transitions from spherical to cylindrical micelles are observed upon increasing concentration. ${ }^{38}$ The presence of rod-like micelles was confirmed by atomic force microscopy images (AFM) in samples prepared from concentrated solutions (see SI file, Fig. S3). In the case of the sample containing $\mathrm{F}_{4} \mathrm{R}_{4}$ at $100 \mathrm{mg} / \mathrm{ml}$, fitting parameters indicated the presence of cylindrical micelles with inner radius $2.0 \pm 1.7 \mathrm{~nm}$ and shell thickness of $4.2 \mathrm{~nm}$, in close agreement with values found in less concentrated solution, whereas mass fractal components were used to fit high- $q$ region for both formulations giving radius of gyration values around $0.8 \mathrm{~nm}$, also in agreement with small oligomers found previously. In the very wide-angle region, a Bragg peak at $q=5.26 \mathrm{~nm}^{-1}$ was noted, corresponding to a repeat distance of $2 \pi / 5.26=1.19 \mathrm{~nm}$. This peak is consistent with inter-sheet separation between $\beta$-sheets ${ }^{34}$ and this provides support for the assignment of $\beta$-sheet content identified in FTIR assays (see Fig. 1C). 


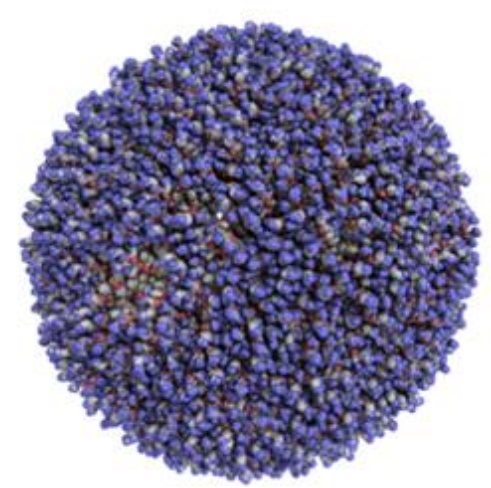

(A)
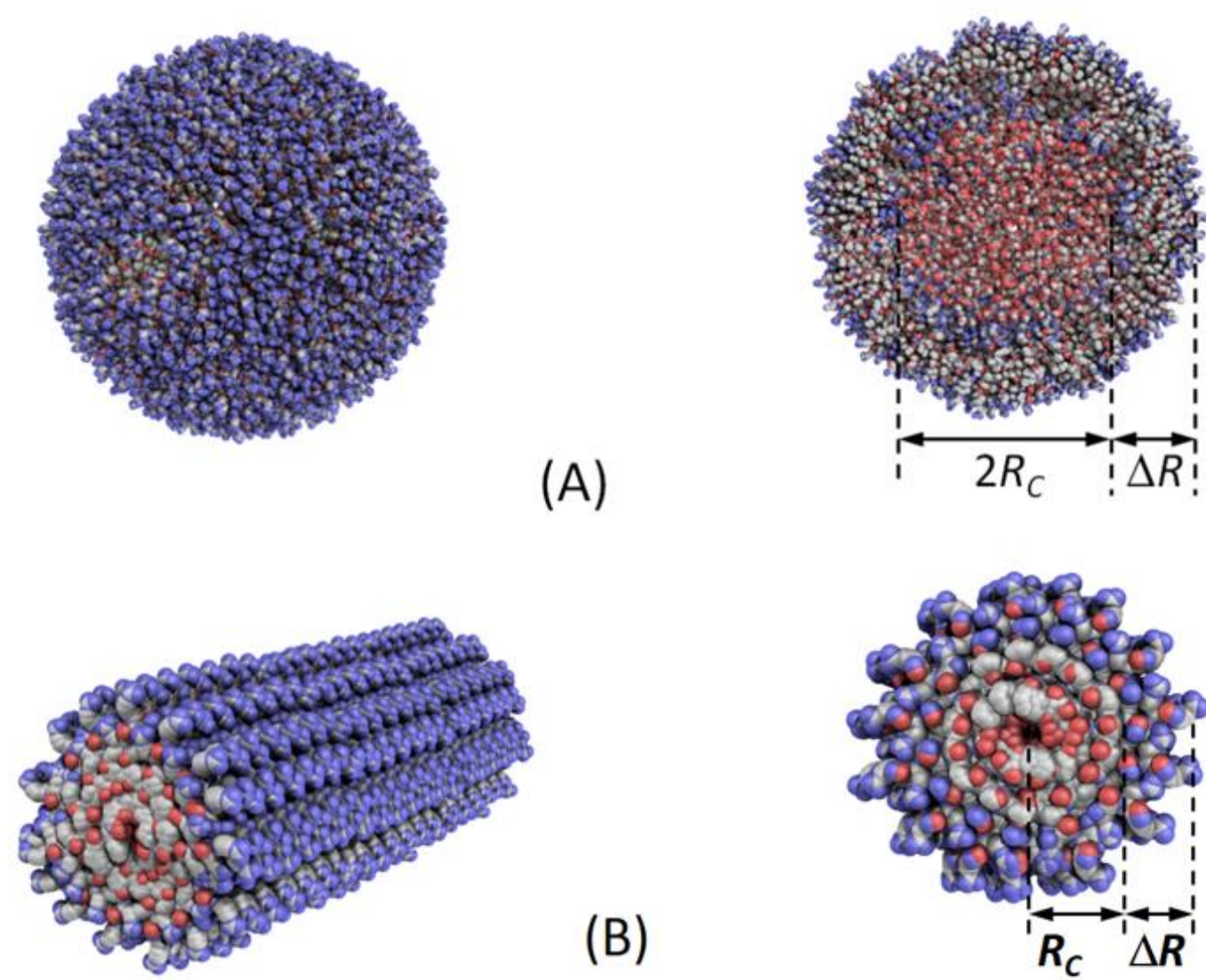

(B)
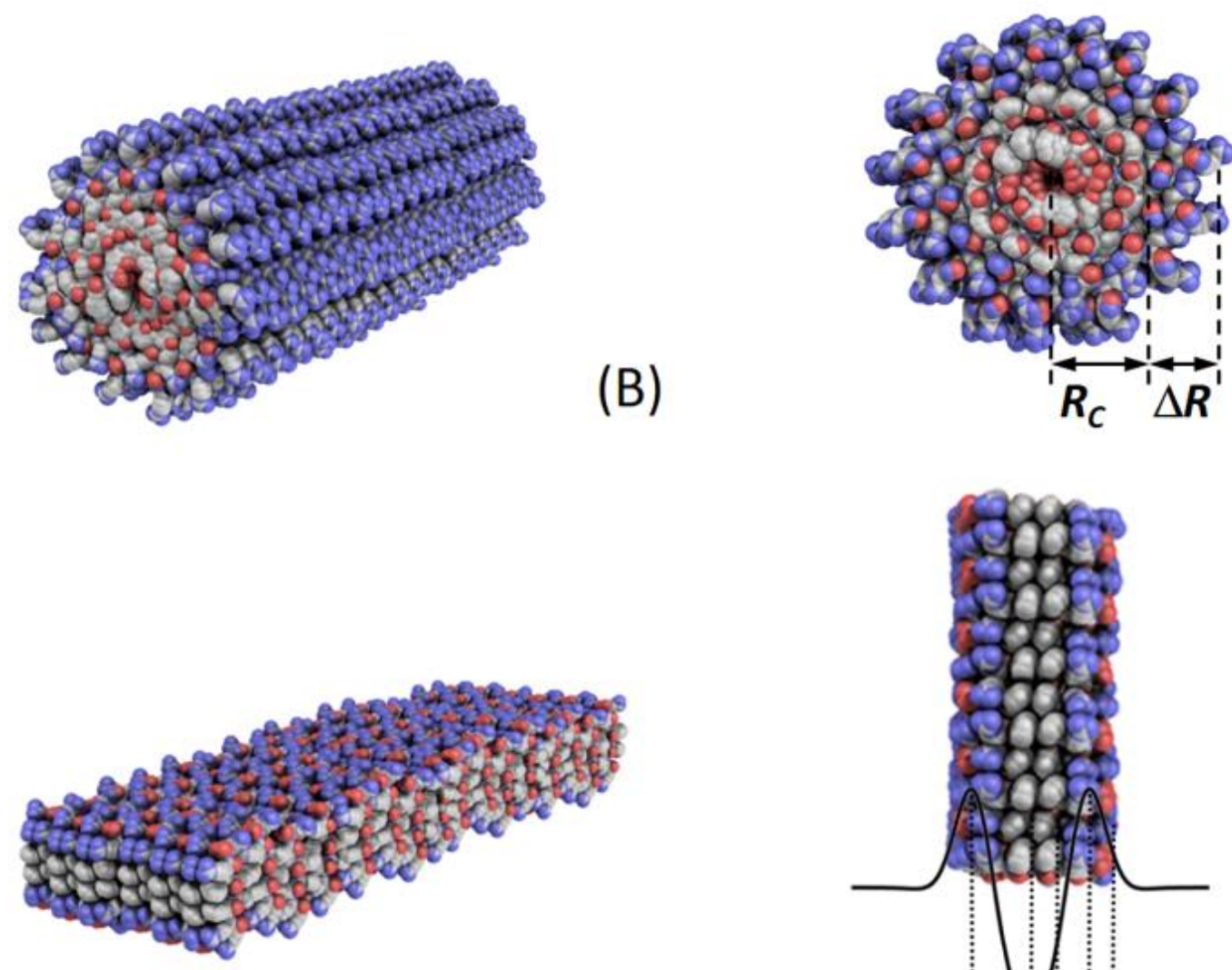

(C)

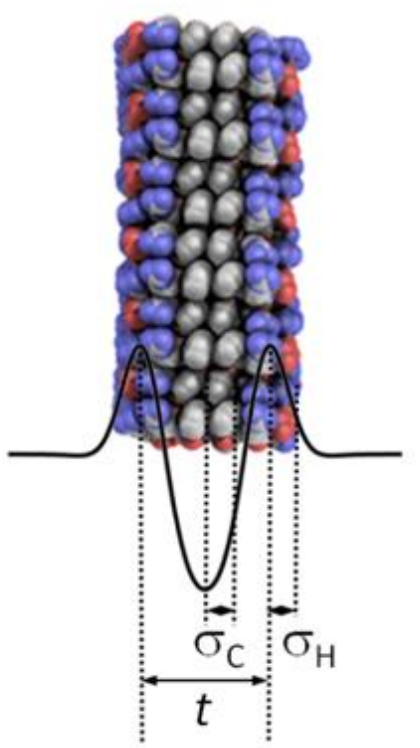

Figure 4: proposed models (not to scale) gathering data from microscopy images (cryoEM and AFM) and SAXS data fitting. The column in the right shows cross-section views of nanostructures alongside structural parameters derived from SAXS fits. The $\mathrm{F}_{4} \mathrm{R}_{4}$ diblock is found to form (A) spherical vesicles at $10 \mathrm{mg} / \mathrm{ml}$ and (B) cylindrical micelles at 50 and $100 \mathrm{mg} / \mathrm{ml}$. The $\mathrm{R}_{2} \mathrm{~F}_{4} \mathrm{R}_{2}$ bolaamphiphilic self-assembles into (C) tape-like assemblies across the concentration range investigated. 
Model fits were also carried out on SAXS data from samples prepared with the bolaamphiphile $\mathrm{R}_{2} \mathrm{~F}_{4} \mathrm{R}_{2}$. In contrast to the diblock peptide, scattering curves from solutions of this peptide exhibit similar shapes across the concentration range, suggesting that particles with similar morphology are present in the solutions. AFM topography images from solutions containing $100 \mathrm{mg} / \mathrm{ml} \mathrm{R}_{2} \mathrm{~F}_{4} \mathrm{R}_{2}$ also indicate the presence of long nanotapes (SI file, Fig. S4). SAXS data are characterized by a plateau in the intermediate $q$-range, separating large-scale features in the low- $q$ region and local-structure scattering at wide angles. The profiles have been fitted through the combination of the cross-section bilayer form factor proposed by Pabst et al.$^{39}$ and the mass fractal form factor used above to describe small oligomers. The bilayer form factor uses the summation of three Gaussian functions to describe the cross-section electron density profile of flat structures and its suitability for fitting SAXS data from $\mathrm{R}_{2} \mathrm{~F}_{4} \mathrm{R}_{2}$ solutions is consistent with the presence of flat nanotapes indicated by cryo-EM and AFM images. Two Gaussian functions in the model outline the arginine polar heads at nanotape/solvent interfaces and the third Gaussian is used for describing the hydrophobic core composed by a tetraphenylalanine segment. The bilayer model, which has been widely used to fit flat structures made from self-assembling arginine-based SLPs, ${ }^{18}$ is sketched alongside with the Gaussian functions used for describing the cross-section electron density profile in Figure 4C. Thicknesses of flat structures could be estimated from the fitting parameters by adding the center-to-center separation between Gaussian functions related to polar heads at both interfaces $(t)$ and the standard deviation associated to these polar groups $\left(\sigma_{\mathrm{H}}\right)$, leading to thickness values of 4.5 and $3.2 \mathrm{~nm}$, respectively, for samples containing 10 and $50 \mathrm{mg} / \mathrm{ml}$ peptide. In samples from $100 \mathrm{mg} / \mathrm{ml}$ solutions, SAXS indicates a layer thickness of $6.1 \mathrm{~nm}$, consistent with heights found in AFM assays (SI, Fig. S4). These values indicate that the assemblies are likely composed by bolamphiphile layers where 
peptide strands are oriented perpendicularly to the plane of the tapes, and arginine headgroups decorate both interfaces (see Fig. 4C). The size of an extended octameric amino acid sequence ${ }^{14,15}$ is estimated to be $8 \times 0.34=2.72 \mathrm{~nm}$ and the thicknesses derived above are compatible with interdigitated peptide monolayers. ${ }^{7}$ Interdigitation likely hinders alignment of termini arginines, weakening H-bonding formation between adjacent strands, in agreement with absence of $\beta$-sheet pairing in bolaamphiphilic aggregates.

The structural data presented above unequivocally demonstrate that morphology is drastically affected by the amphipathic design of peptides in the formulation. Since both constructs are identical in amino acid composition, this polymorphism is obviously correlated to the molecular layout of each sequence. To get insights into this correlation, the underlying forces involved in the self-assembly of SLPs should be considered. In general, supramolecular assembly of SLPs is driven by a delicate balance where the major contributions are from the hydrophobic effect, H-bonding and Coulombic electrostatic interaction. ${ }^{6}$ In the case of amphiphiles investigated here, Coulombic forces are repulsive because only positively-charged groups are present in the peptides. Also, FTIR and CD spectra indicate low $\beta$-sheet content, suggesting that $\mathrm{H}$-bonds have a minor role for their stabilization. Therefore, hydrophobic attraction is likely the dominant force holding adjacent strands together. Such a prominent role of hydrophobic attraction is also consistent with the curvature exhibited by micelles and vesicles, found especially in $F_{4} R_{4}$ aggregates. Molecular simulations studies conducted in lipopeptides, which are molecules exhibiting a diblock design where an amino acid segment appears linked to an alkyl chain, indicated that systems where hydrophobic interactions overwhelm $\mathrm{H}$ bonding are prone to self-assemble into particles with globular symmetry where ordering of $\beta$-sheets is weakened to fit into spherical interfacial curvature. ${ }^{30}$ Upon increasing 
hydrogen bonding, the spherical symmetry is broken and assembly into 1D (fiber-like) structures arises with $\beta$-sheets growing along the long axis of the fibers. These observations are in close agreement with behavior found in highly concentrated $\mathrm{F}_{4} \mathrm{R}_{4}$ solutions for which SAXS revealed cylindrical micelles accompanied by the appearance of $\beta$-sheets (Fig. 3B, inset). Self-assembly of $\mathrm{R}_{2} \mathrm{~F}_{4} \mathrm{R}_{2}$ into nanotapes may be explained in terms of the symmetric design of the molecule. Actually, the presence of arginines at both termini favors the creation of aqueous interfaces on both sides to give raise to planar structures. In this case, the hydrophobic effect drives lateral association between peptides and $\pi$-stack interactions between phenylalanine side chains provides directionality along the longitudinal axis of the nanotapes.

\section{Diblock $F_{4} R_{4}$ and bolaamphiphile $R_{2} F_{4} R_{2}$ surfactant-like peptides induce different effects in SK-MEL-28 tumor cells:}

Our cryo-EM and SAXS findings point out to the different supramolecular arrangements formed by $F_{4} R_{4}$ and $R_{2} F_{4} R_{2}$ peptides. To evaluate if these self-assembled peptide structures lead to different biological effects, in vitro studies were conducted with the SK-MEL-28 tumor cell line. MTT assays were performed to assess the metabolic viability following cell exposure to $\mathrm{F}_{4} \mathrm{R}_{4}$ or $\mathrm{R}_{2} \mathrm{~F}_{4} \mathrm{R}_{2}$. Incubation was performed for $4 \mathrm{~h}$ with peptide concentrations ranging from 0.5 to $6.6 \mathrm{mg} / \mathrm{mL}$ and the results showed that both $\mathrm{F}_{4} \mathrm{R}_{4}$ and $\mathrm{R}_{2} \mathrm{~F}_{4} \mathrm{R}_{2}$ reduce cell metabolic viability, although with different potency. Fig. 5A shows the sigmoidal concentration-response profile of each peptide. The measured $\mathrm{EC}_{50}$ values for $\mathrm{F}_{4} \mathrm{R}_{4}$ and $\mathrm{R}_{2} \mathrm{~F}_{4} \mathrm{R}_{2}$ are 0.39 and $0.69 \mathrm{mg} / \mathrm{mL}$, respectively.

To further explore the different cellular response to diblock $F_{4} R_{4}$ and bolaamphiphile homolog $\mathrm{R}_{2} \mathrm{~F}_{4} \mathrm{R}_{2}$, SK-MEL-28 cells were incubated for 4 and $24 \mathrm{~h}$ with each peptide at the respective $\mathrm{EC}_{50}$. Representative phase contrast microscopy images of 
the cells after peptide incubation are shown in Fig. 5B. The lower cellular density detected following exposure to $\mathrm{F}_{4} \mathrm{R}_{4}$, compared to vehicle control, is attributed to the increased cell death, assessed by PI uptake (Fig. 5C), and the decreased number of live cells following such treatment (Fig. 5D). The optically dense structures appearing as dark objects in Fig. 5B, at the $4 \mathrm{~h}$ time point, indicate unviable cells. These findings differ from those found in the bolaamphiphile group. The induction of cell death and the decrease in the number of cells after incubation with $\mathrm{R}_{2} \mathrm{~F}_{4} \mathrm{R}_{2}$ for up to $24 \mathrm{~h}$ were considerably less pronounced than the shtainad with the dihlorl ontamar (Fir 5C_n)

(A)

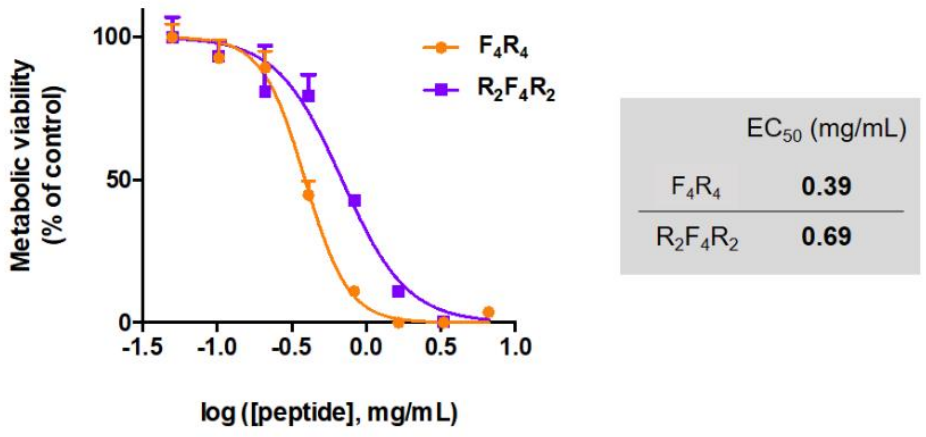

(B)
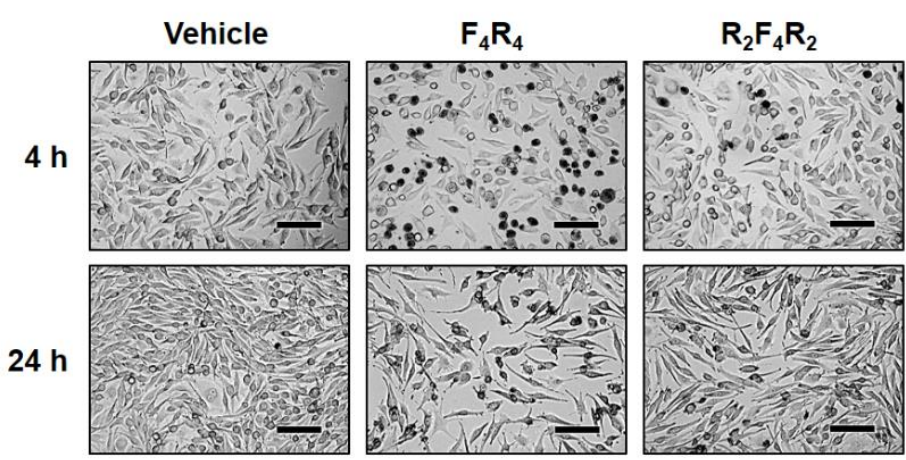

(C)

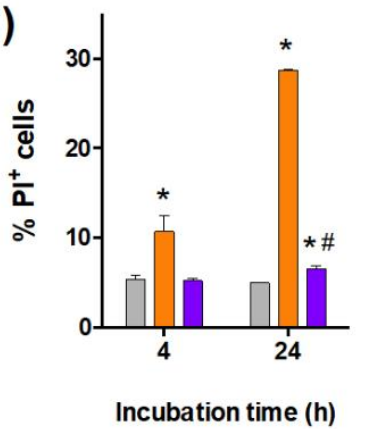

(D)

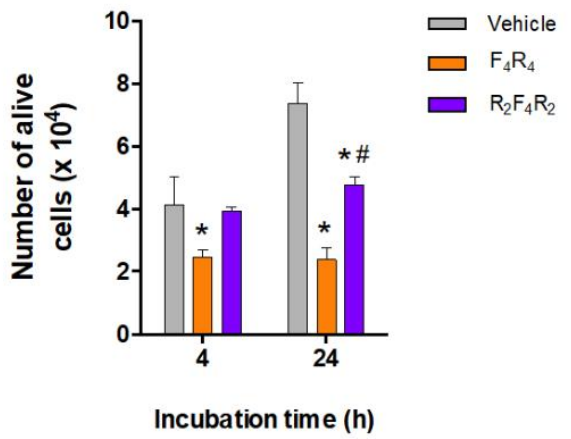


Figure 5: Cell death and changes in metabolic viability induced by diblock $F_{4} R_{4}$ and bolaamphiphile $\mathrm{R}_{2} \mathrm{~F}_{4} \mathrm{R}_{2}$ peptides in SK-MEL-28 tumor cells. (A) MTT assays were performed to evaluate the metabolic viability of SK-MEL-28 cells incubated for $4 \mathrm{~h}$ with increasing concentrations ( 0.5 to $6.6 \mathrm{mg} / \mathrm{mL}$ ) of $\mathrm{F}_{4} \mathrm{R}_{4}$ or $\mathrm{R}_{2} \mathrm{~F}_{4} \mathrm{R}_{2}$. Graph shows concentration-response curves for each peptide, from a representative experiment. The metabolic viability of the vehicle group was set to $100 \%$. Table on the right indicates the determined $\mathrm{EC}_{50}$ values. (B) Representative phase contrast microscopy images of SKMEL-28 cells incubated for 4 and $24 \mathrm{~h}$ with each peptide at the respective $\mathrm{EC}_{50}$. Scale bar, $100 \mu \mathrm{m}$. The percentage of PI-positive cells and the number of alive cells following that exposure to $\mathrm{F}_{4} \mathrm{R}_{4}$ or $\mathrm{R}_{2} \mathrm{~F}_{4} \mathrm{R}_{2}$ are shown on $(\mathrm{C})$ and (D), respectively. *, $\mathrm{P}<0.05$ compared with the corresponding vehicle group; \#, $\mathrm{P}<0.05$ compared with the corresponding $\mathrm{F}_{4} \mathrm{R}_{4}$ group; one-way ANOVA/Bonferroni's post-test. Data (mean $\pm \mathrm{SD}$ ) are representative of three independent experiments.

The different cellular effects of $\mathrm{F}_{4} \mathrm{R}_{4}$ and $\mathrm{R}_{2} \mathrm{~F}_{4} \mathrm{R}_{2}$ may reflect the access of the peptide arrangements to the intracellular space. Fluorescence assays were performed to investigate that, following a 30-min peptide incubation period. The results revealed that $\mathrm{F}_{4} \mathrm{R}_{4}$ was taken up by more than $50 \%$ of the cells (mean $\pm \mathrm{SD}=56.3 \pm 3.8 \%$ ), while only $19.0 \pm 3.5 \%$ (mean $\pm \mathrm{SD}$ ) of the cells had $\mathrm{R}_{2} \mathrm{~F}_{4} \mathrm{R}_{2}$ uptake ( $\mathrm{p}<0.05$, Student's $t$-test) (Figs. 6A-ii and A-iv, 6B; SI file Fig. S7). Such a low percentage of cells exhibiting $R_{2} F_{4} R_{2}$ intracellular uptake is consistent with poor delivery capabilities previously found in arginine-capped bolamphiphiles ${ }^{34}$ and potentially explains the low cell death induction observed for this peptide group.

Once cell-internalized, both peptides exhibit a common destiny. Images in Fig. 6A show peptide-related fluorescent signals distributed throughout the cytoplasm and accumulated in the nucleolus, a subnuclear organelle involved in rRNA transcription and ribosome biogenesis, among other functions. ${ }^{40}$ Nucleoli were identified based on the DNA staining pattern of cell nuclei with DAPI. ${ }^{41}$ The negative charge of nucleolar components may have contributed to this, creating an environment favorable for the 
retention of cationic molecules, such as $\mathrm{F}_{4} \mathrm{R}_{4}$ and $\mathrm{R}_{2} \mathrm{~F}_{4} \mathrm{R}_{2}$. Indeed, positively charged peptides were previously found in nucleolus compartment after cellular uptake. ${ }^{42-44}$

(A)

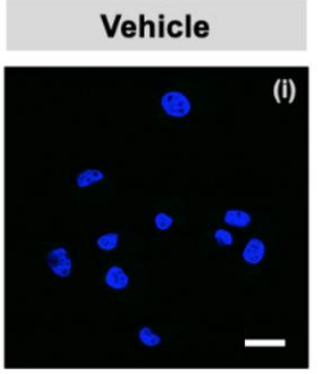

Labeled peptide DAPI
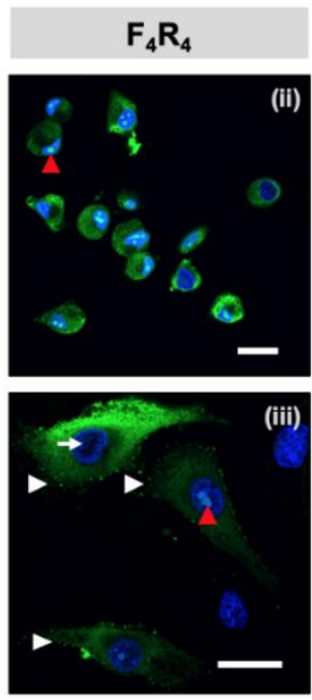
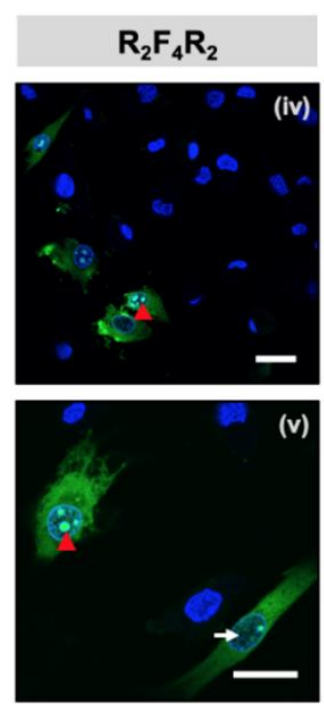

(B)

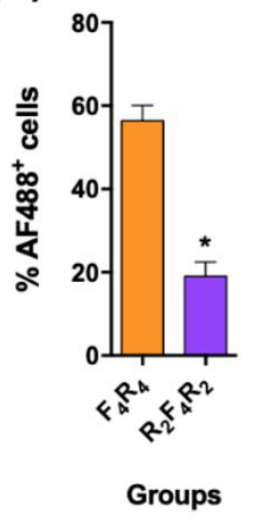

(C)
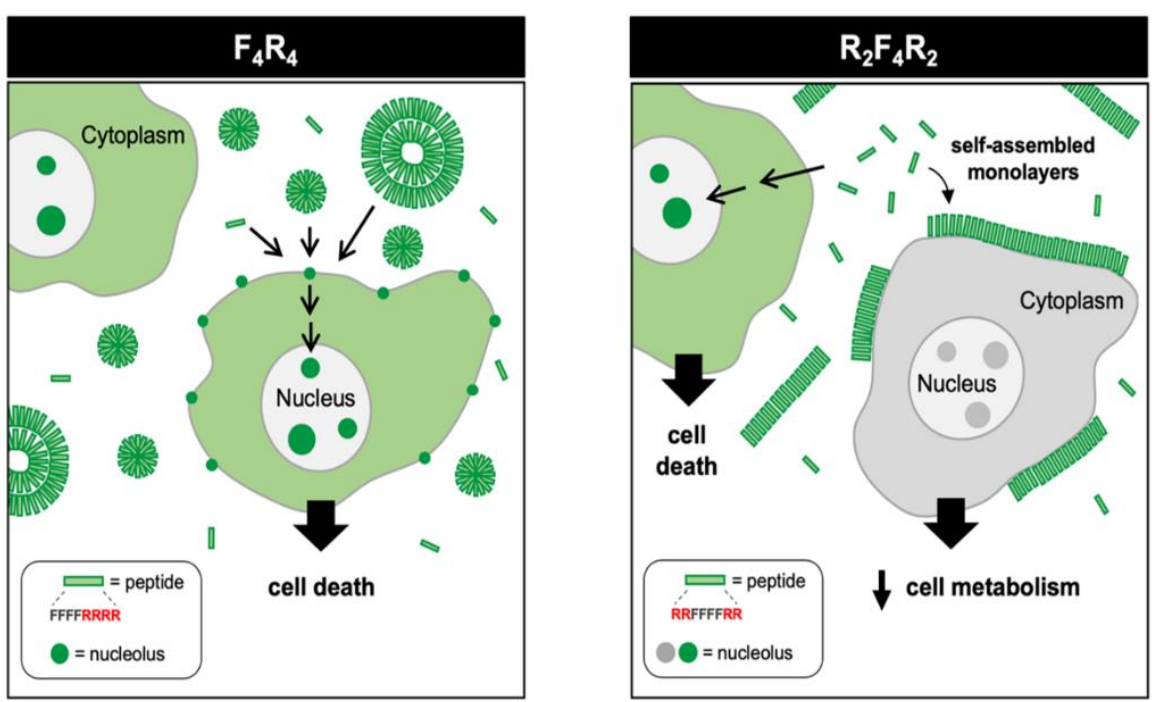

Figure 6: Internalization and subcellular distribution of diblock $\mathrm{F}_{4} \mathrm{R}_{4}$ and bolaamphiphile $\mathrm{R}_{2} \mathrm{~F}_{4} \mathrm{R}_{2}$ peptides in SK-MEL-28 cells. (A) Representative confocal fluorescence images of cells following 30-min incubation with biotin-labeled $F_{4} R_{4}$ (panels ii and iii) or $R_{2} F_{4} R_{2}$ (panels iv and v) at their respective $\mathrm{EC}_{50}$. Vehicle (panel i) was used as a control. DAPI stains nuclei (blue) and peptides (green) were detected with Alexa Fluor® 488 (AF488)conjugated streptavidin staining. Arrows indicate chromatin condensation on cells with peptide uptake. White arrowheads indicate fluorescent puncta on the surface of cells exposed to diblock $\mathrm{F}_{4} \mathrm{R}_{4}$. Detection of peptide-related fluorescence in nucleoli is highlighted by red arrowheads. Nucleoli was identified based on the DAPI labeling pattern of this subnuclear structure. Scale bar, $25 \mu \mathrm{m}$. The graph in (B) shows the percentage of cells with $\mathrm{F}_{4} \mathrm{R}_{4}$ or $\mathrm{R}_{2} \mathrm{~F}_{4} \mathrm{R}_{2}$ uptake. ${ }^{*} \mathrm{P}<0.05$; Student's $t$-test. Data are presented as mean $\pm \mathrm{SD}$ of two independent experiments. (C) Cartoon (not to scale) 
summarizing the proposed cellular uptake and effects of $\mathrm{F}_{4} \mathrm{R}_{4}$ and $\mathrm{R}_{2} \mathrm{~F}_{4} \mathrm{R}_{2}$. Both the monomeric (represented by green glow within cells) and spherical assembled peptide forms should be able to get into cells and contribute to cell death. The tape-like structures formed by $\mathrm{R}_{2} \mathrm{~F}_{4} \mathrm{R}_{2}$ peptide should hardly be internalized. Straight arrow $(\rightarrow)$ indicates cellular internalization of the peptide arrangements. The green points at the cell surface indicate the anchorage of peptides in raft-like membrane regions, as detected at (A- iii).

The obtained results provide mechanistic insights into the cellular effects of $F_{4} R_{4}$ and $\mathrm{R}_{2} \mathrm{~F}_{4} \mathrm{R}_{2}$. It seems that accumulation of peptides in the nucleolus perturbs the function of this organelle and ultimately triggers molecular pathways leading cells to cycle arrest and death. ${ }^{45,46}$ This rationale is in accordance with the observation of condensed chromatin in cells showing peptide uptake (Fig. 6A-iii and v). It is noteworthy here that tumor cells, such as SK-MEL-28, are particularly vulnerable to nucleolar stress, having in mind the intense biosynthesis and activity of ribosomes in highly metabolic and proliferating cells. ${ }^{47,48}$

At a closer inspection, image in Fig. 6A-iii reveals a punctate pattern of $\mathrm{F}_{4} \mathrm{R}_{4}$ at the cell surface, which may be due to anchorage of peptide arrangements at raft-like membrane regions rich in negatively charged molecules. Such a mechanism would be consistent with the previously reported for other arginine-rich peptides. ${ }^{49,50}$ Endocytosis is a feasible internalization route. ${ }^{49,51}$ On the other hand, the same membrane distribution is not detected for the bolaamphiphile isomer (Fig. 6A-v). It is possible that nanotapes formed by $\mathrm{R}_{2} \mathrm{~F}_{4} \mathrm{R}_{2}$ do not accumulate in clusters on the membrane, impairing their detection as fluorescent dots. Indeed, biotin-labelled peptides were found to retain selfassembly behavior similar to those observed in structural assays and the formation of flat assemblies by $\mathrm{R}_{2} \mathrm{~F}_{4} \mathrm{R}_{2}$ chains was detected by $\mathrm{AFM}$ assays in samples prepared from solutions at concentrations closer to $\mathrm{EC}_{50}$ (SI file, Figs. S5 and SI). In this case, bigger $\mathrm{R}_{2} \mathrm{~F}_{4} \mathrm{R}_{2}$ supramolecular assemblies possibly face limitations on cellular uptake, which may explain the data in Fig. 6B. This assumption is supported by the previous 
demonstration that filamentous peptide assemblies are difficult to internalize in cells, despite cellular uptake of the monomeric and the spherical assembled peptide counterparts. ${ }^{52}$ The proposed molecular mechanisms for $\mathrm{F}_{4} \mathrm{R}_{4}$ and $\mathrm{R}_{2} \mathrm{~F}_{4} \mathrm{R}_{2}$ interactions with cells are shown in Fig. 6C.

Regarding $\mathrm{R}_{2} \mathrm{~F}_{4} \mathrm{R}_{2}$ bolaamphiphile, it is noteworthy that peptide concentration giving half-maximum MTT signal did not led to significant changes in the number of viable cells or in the induction of cell death following a $4 \mathrm{~h}$ incubation period. One possibility to be considered is that interaction of $\mathrm{R}_{2} \mathrm{~F}_{4} \mathrm{R}_{2}$ nanotapes with plasma membrane hampers activation of signaling receptors, which may affect cell metabolism and therefore the MTT results. This hypothesis is consistent with previous report showing cellular effects of peptide-based fibers retained in the pericellular region. ${ }^{53}$

\section{CONCLUSIONS}

We presented a broad study on self-assembly and cellular effects of selfassemblies based on SLPs designed with two amphipathic configurations, the diblock octamer $\mathrm{F}_{4} \mathrm{R}_{4}$ and the bolaamphiphile analog $\mathrm{R}_{2} \mathrm{~F}_{4} \mathrm{R}_{2}$. Our results show close dependence between the amphipathic design and the morphologies of resulting nanostructures. The presence of micellar assemblies coexisting with vesicles was detected in solutions containing $\mathrm{F}_{4} \mathrm{R}_{4}$ sequences, whereas the presence of tape-like structures was found in samples prepared with the bolaamphiphile variant. The formation of vesicles by $F_{4} R_{4}$ diblocks indicates the ability of this construct to produce structures decorated with arginine groups, an arrangement potentially useful in nanoparticles intended for intracell delivery. ${ }^{54}$ On the other hand, organization into tape-like structures exhibited by $R_{2} F_{4} R_{2}$ assemblies is coherent with the propensity shown by bolaamphiphiles to form 
monolayers, a feature that may be attractive for producing functionalized coated surfaces. ${ }^{34}$

Both designs investigated here show low propensity to form $\beta$-sheets. Indeed, the bolamphiphilic construct does not generate $\beta$-sheets at all, and only at very high concentrations of $\mathrm{F}_{4} \mathrm{R}_{4}$ are a small fraction detected. These findings contrast with alternating $[\mathrm{RF}]$ sequences that self-assemble into fibrillar assemblies endowed with clear amyloidogenic features. ${ }^{13-15}$ This is closely related to the design of sequences, where the presence of a tetramer displaying only phenylalanine residues, depresses the formation of H-bonds between adjacent strands. The low number of $\mathrm{H}$-bonds along with the presence of evenly charged groups presumably leading to repulsive electrostatics indicates that hydrophobic attraction is the major energetic contribution for the self-assembly. Such a prominent role of hydrophobic attraction is also consistent with curvature exhibited by micelles and vesicles, found especially in $\mathrm{F}_{4} \mathrm{R}_{4}$ aggregates and are in close agreement with previous molecular simulation results. ${ }^{30}$ Self-assembly of $\mathrm{R}_{2} \mathrm{~F}_{4} \mathrm{R}_{2}$ into nanotapes may be explained in terms of the symmetric design of the molecule, with the presence of arginines at both termini favoring the formation of aqueous interfaces at both sides of a planar structure. In this case, in addition to hydrophobic attraction promoting lateral association between strands, $\pi$-stack interactions between phenylalanine side chains also play a relevant role to provide directionality along the longitudinal axis of nanotapes.

We also examined the effects of these amphipathic layouts toward SK-MEL-28 tumor cells. Our experimental findings clearly show that the cellular responses to these isomeric forms are remarkably different. Both isomers have been found to present cellpenetrating capabilities, however, with different cell uptake effectiveness. The $\mathrm{F}_{4} \mathrm{R}_{4}$ peptide, which was found to form vesicle-like superstructures, was able to gain access to intracellular space and trigger cell death with higher efficiency in comparison to the 
bolaamphiphile construct. From a physicochemical perspective, this could be related to the surface charge density which is presumably higher in the tetra-arginine block of

$\mathrm{F}_{4} \mathrm{R}_{4}{ }^{55,56}$ In this case, interaction with anionic domains at the cell membrane surface could be favored, contributing to internalization and cell death. This peptide appears distributed across the cytoplasm and, once internalized in the nucleus is concentrated in nucleoli. It should be noted that the monomeric form of the peptide may also enter cells and impair cell viability.

While most of cells incubated with $\mathrm{F}_{4} \mathrm{R}_{4}$ showed uptake of peptide, the same does not occur with the bolaamphiphile variant. The extended $\mathrm{R}_{2} \mathrm{~F}_{4} \mathrm{R}_{2}$ nanostructures face restrictions on internalization and practically do not trigger cell death. Despite this, our MTT assay results provide evidence that $\mathrm{R}_{2} \mathrm{~F}_{4} \mathrm{R}_{2}$ reduces cellular metabolic activity, indicating that this peptide also affects cell machinery. Overall, the data presented show a notable influence of amphipathic layout not only in the peptide self-assembly of these arginine-enriched sequences but also in the biological significance of these structures. Furthermore, our evidence that $\mathrm{F}_{4} \mathrm{R}_{4}$ and $\mathrm{R}_{2} \mathrm{~F}_{4} \mathrm{R}_{2}$ SLPs interfere with cellular activity in different ways demonstrate that amphipathic design is a relevant variable to be considered in the modulation of different cellular responses. These findings may assist in optimizing the production of synthetic bioactive sequences, especially those where arginine residues play a paramount role such is the case for most cell penetrating and many antimicrobial peptides.

\section{ACKNOWLEDGEMENTS}

This work was supported by the Sao Paulo Research Foundation (FAPESP), under grant $n^{\circ}$ 2016/24409-3. E.R.S. is recipient of a research fellowship from Brazilian National Council for Scientific and Technological Development (CNPq), n 310916/2019- 
4. L.R.M. and R.Y.Y. acknowledge CAPES for a fellowship granted to the Graduate Program in Molecular Biology of the Federal University of Sao Paulo. R.B.A was supported by CNPq (grant n 150161/2017-4). I.W.H. thanks EPSRC (UK) for the award of a Platform Grant (ref. EP/L020599/1). W.A.A. is supported by CNPq (grant $\mathrm{n}^{\circ}$ 302923/2015-2), the National Institute of Science and Technology in Bioanalytics (FAPESP grant no. 2014/50867-3 and CNPq grant no. 465389/2014-7), and FAPESP (grant nos. 2015/24018-1, 2017/02317-2). SAXS data were collected at SOLEIL under proposal $n^{\circ} 20140919$ and at LNLS under proposal $n^{\circ} 20160884$, and we are grateful to Javier Perez (SOLEIL) and Vesna Stanic (LNLS) for technical assistance during the experiments. AFM assays were performed at LNNano under proposal AFM-26338, and Dr. Carlos Costa and Cleyton Biffe are kindly acknowledged for assistance. Paulo Costa (Analica LTDA, Sao Paulo) is acknowledged for proving access to a Park XE7 AFM instrument.

\section{SUPPORTING INFORMATION}

Chromatography and mass spectroscopy data, table with SAXS fitting parameters, supplementary cell fluorescence images and AFM images.

\section{REFERENCES}

1 P. Chakraborty and E. Gazit, ChemNanoMat, 2018, 4, 730-740.

2 D. Tesauro, A. Accardo, C. Diaferia, V. Milano, J. Guillon, L. Ronga and F. Rossi, Molecules, , DOI:10.3390/molecules24020351.

3 I. W. Hamley, Chem. Rev., 2017, 117, 14015-14041.

4 E. R. Silva, G. Cooney, I. W. Hamley, W. A. Alves, S. Lee, B. F. O’Connor, M. Reza, J. Ruokolainen and D. Walls, Soft Matter, , DOI:10.1039/C6SM01618A.

5 A. Lampel, R. V Ulijn and T. Tuttle, Chem. Soc. Rev., 2018, 47, 3737-3758.

6 H. Cui, M. J. Webber and S. I. Stupp, Biopolymers, 2010, 94, 1-18.

7 E. R. da Silva, W. A. Alves, V. Castelletto, M. Reza, J. Ruokolainen, R. Hussain and I. W. Hamley, Chem. Commun., 2015, 51, 11634-11637.

8 H. Cui, A. G. Cheetham, E. T. Pashuck and S. I. Stupp, J. Am. Chem. Soc., 2014, 
136, 12461-12468.

9 Y. Wang, K. Kaur, S. J. Scannelli, R. Bitton and J. B. Matson, J. Am. Chem. Soc., 2018, 140, 14945-14951.

10 L. Chen, J. Feng, D. Yang, F. Tian, X. Ye, Q. Qian, S. Wei and Y. Zhou, Chem. Sci., 2019, 10, 8171-8178.

11 F. Zhao, H. Guo, Z. Zhang, J. Ye, L. Liu, C.-X. Zhao and Z. Shao, J. Mater. Chem. B, 2017, 5, 5189-5195.

12 N. R. Lee, C. J. Bowerman and B. L. Nilsson, Biomacromolecules, 2013, 14, 3267-3277.

13 M. S. Liberato, S. Kogikoski, E. R. da Silva, R. H. Silva, V. X. Oliveira, L. P. Scott, R. A. Ando, W. A. Alves and M. D. Coutinho-Neto, J Phys Chem B, 2013, 117, 733-740.

14 C. C. Decandio, E. R. Silva, I. W. Hamley, V. Castelletto, M. S. Liberato, V. X. Oliveira, C. L. P. Oliveira and W. A. Alves, Langmuir, 2015, 31, 4513-4523.

15 E. R. Silva, E. Listik, S. W. Han, W. A. Alves, B. M. Soares, M. Reza, J. Ruokolainen and I. W. Hamley, Biophys. Chem., 2018, 233, 1-12.

16 C. Bechara and S. Sagan, Febs Lett., 2013, 587, 1693-1702.

17 L. R. de Mello, I. W. Hamley, V. Castelletto, B. B. M. Garcia, S. W. Han, C. L. P. Oliveira and E. R. Silva, J. Phys. Chem. B, , DOI:10.1021/acs.jpcb.9b05512.

18 V. Castelletto, C. J. C. Edwards-Gayle, I. W. Hamley, G. Barrett, J. Seitsonen and J. Ruokolainen, ACS Appl. Mater. Interfaces, 2019, 11, 9893-9903.

19 V. Castelletto, R. H. Barnes, K.-A. Karatzas, C. J. C. Edwards-Gayle, F. Greco, I. W. Hamley, R. Rambo, J. Seitsonen and J. Ruokolainen, Biomacromolecules, 2018, 19, 2782-2794.

20 M. Wojdyr, J. Appl. Crystallogr., 2010, 43, 1126-1128.

21 I. Bressler, J. Kohlbrecher and A. F. Thunemann, J. Appl. Crystallogr., 2015, 48, 1587-1598.

22 L. C. Crowley, A. P. Scott, B. J. Marfell, J. A. Boughaba, G. Chojnowski and N. J. Waterhouse, Cold Spring Harb. Protoc. , 2016, 2016, pdb.prot087163.

23 M. Shenkin, R. Babu and R. Maiese, Cytom. Part B Clin. Cytom., 2007, 72B, 427-432.

24 R. B. de Aguiar, C. B. Parise, C. R. T. Souza, C. Braggion, W. Quintilio, A. M. Moro, F. L. Navarro Marques, C. A. Buchpiguel, R. Chammas and J. Z. de Moraes, Cancer Lett., 2016, 371, 151-160.

25 J. Aguiar, P. Carpena, J. A. Molina-Bolívar and C. Carnero Ruiz, J. Colloid Interface Sci., 2003, 258, 116-122.

26 F. M. Winnik, Chem. Rev., 1993, 93, 587-614.

27 B. Nordén, A. Rodger, T. Dafforn and Royal Society of Chemistry (Great Britain), Linear dichroism and circular dichroism : a textbook on polarized-light spectroscopy, Royal Society of Chemistry, Cambridge, 2010.

28 A. Barth, Prog Biophys Mol Biol, 2000, 74, 141-173.

29 A. Barth, Biochim. Biophys. Acta - Bioenerg., 2007, 1767, 1073-1101.

30 Y. S. Velichko, S. I. Stupp and M. O. de la Cruz, J. Phys. Chem. B, 2008, 112, 2326-2334.

31 K. Kim and R. A. Friesner, J. Am. Chem. Soc., 1997, 119, 12952-12961.

32 K. Liu, Y. Yao, C. Wang, Y. Liu, Z. Li and X. Zhang, Chem. - A Eur. J., 2012, 18, 8622-8628.

33 A. H. Fuhrhop and T. Y. Wang, Chem. Rev., 2004, 104, 2901-2937.

34 E. R. da Silva, M. N. M. Walter, M. Reza, V. Castelletto, J. Ruokolainen, C. J. Connon, W. A. Alves and I. W. Hamley, Biomacromolecules, 2015, 16, 3180- 
3190.

35 I. W. Hamley, S. Burholt, J. Hutchinson, V. Castelletto, E. R. da Silva, W. Alves, P. Gutfreund, L. Porcar, R. Dattani, D. Hermida-Merino, G. Newby, M. Reza, J. Ruokolainen and J. Stasiak, Biomacromolecules, 2017, 18, 141-149.

36 T. Zemb and P. Lindner, Neutrons, X-rays and light : scattering methods applied to soft condensed matter, Elsevier, Amsterdam ; Boston, 1st edn., 2002.

37 J. S. Pedersen, Adv. Colloid Interface Sci., 1997, 70, 171-210.

38 G. V. Jensen, R. Lund, J. Gummel, T. Narayanan and J. S. Pedersen, Angew. Chemie Int. Ed., 2014, 53, 11524-11528.

39 G. Pabst, M. Rappolt, H. Amenitsch and P. Laggner, Phys Rev E Stat Phys Plasmas Fluids Relat Interdiscip Top., 2000, 62, 4000-4009.

40 T. Pederson, Cold Spring Harb. Perspect. Biol. .

41 F. Pontvianne, M.-C. Carpentier, N. Durut, V. Pavlištová, K. Jaške, Š. Schořová, H. Parrinello, M. Rohmer, C. S. Pikaard, M. Fojtová, J. Fajkus and J. SáezVásquez, Cell Rep., 2016, 16, 1574-1587.

42 E. Vivès, P. Brodin and B. Lebleu, J. Biol. Chem., 1997, 272, 16010-16017.

43 S. Futaki, T. Suzuki, W. Ohashi, T. Yagami, S. Tanaka, K. Ueda and Y. Sugiura, J Biol Chem, 2001, 276, 5836-5840.

44 V. B. Morris and V. Labhasetwar, Biomaterials, 2015, 60, 151-160.

45 S. Boulon, B. J. Westman, S. Hutten, F.-M. Boisvert and A. I. Lamond, Mol. Cell, 2010, 40, 216-227.

46 A. James, Y. Wang, H. Raje, R. Rosby and P. DiMario, Nucleus, 2014, 5, 402426.

47 S. O. Sulima, I. J. F. Hofman, K. De Keersmaecker and J. D. Dinman, Cancer Discov., , DOI:10.1158/2159-8290.CD-17-0550.

48 D. Stępiński, Histochem. Cell Biol., 2018, 150, 607-629.

49 K. Najjar, A. Erazo-Oliveras, J. W. Mosior, M. J. Whitlock, I. Rostane, J. M. Cinclair and J.-P. Pellois, Bioconjug. Chem., 2017, 28, 2932-2941.

50 R. Wallbrecher, T. Ackels, R. A. Olea, M. J. Klein, L. Caillon, J. Schiller, P. H. Bovée-Geurts, T. H. van Kuppevelt, A. S. Ulrich, M. Spehr, M. J. W. AdjoboHermans and R. Brock, J. Control. Release, 2017, 256, 68-78.

51 S. M. Fuchs and R. T. Raines, Biochemistry, 2004, 43, 2438-2444.

52 L. L. Lock, C. D. Reyes, P. Zhang and H. Cui, J. Am. Chem. Soc., 2016, 138, 3533-3540.

53 H. Wang, Z. Feng and B. Xu, Adv. Drug Deliv. Rev., 2017, 110-111, 102-111.

54 J. Yan, N. Korolev, K. D. Eom, J. P. Tam and L. Nordenskiold, Biomacromolecules, 2012, 13, 124-131.

55 H. Binder and G. Lindblom, Biophys J, 2003, 85, 982-995.

56 S. Reißer, E. Strandberg, T. Steinbrecher and A. S. Ulrich, Biophys. J., 2014, 106, 2385-2394. 


\section{TOC Entry}

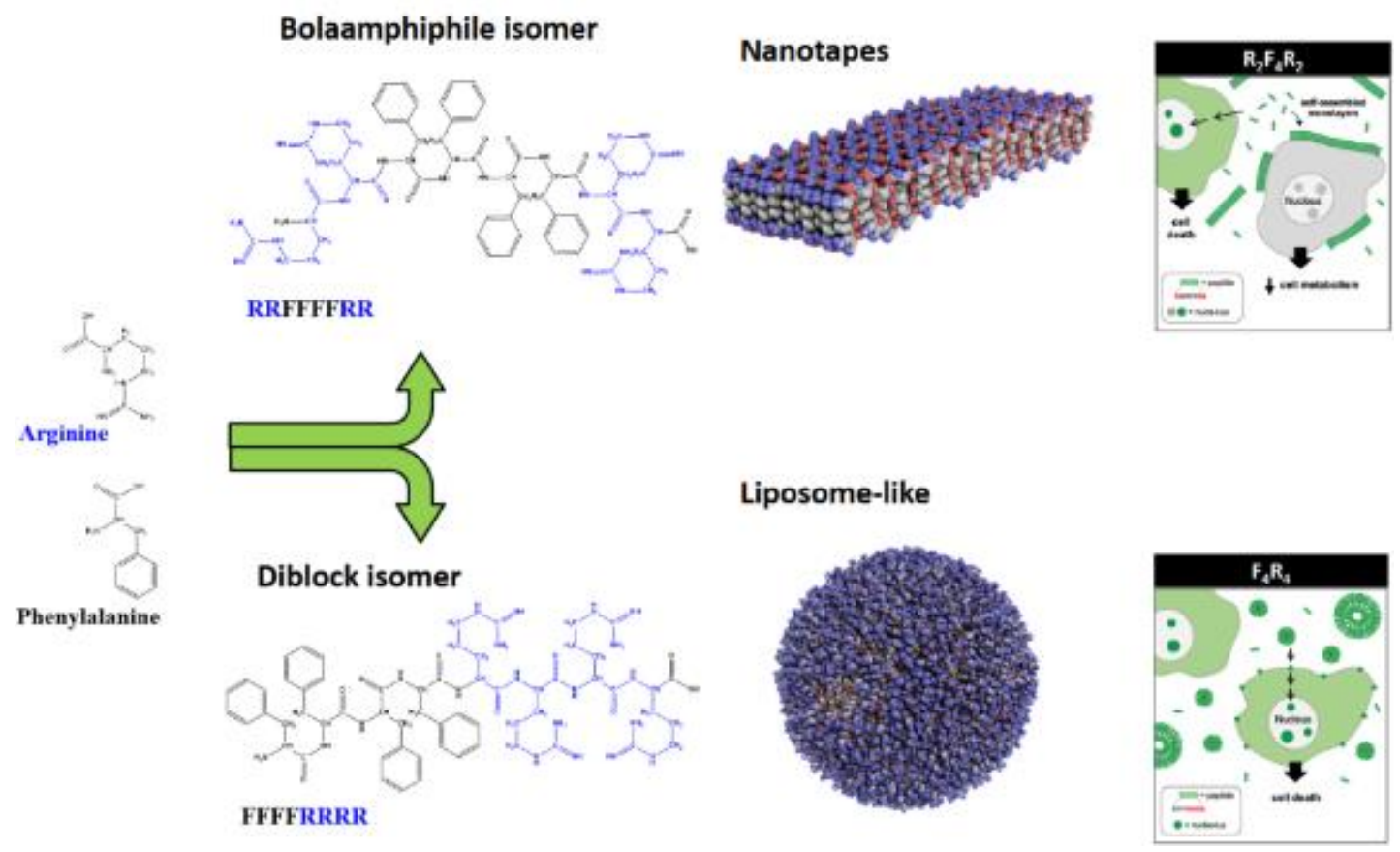

